\title{
Prophylactic Efficacy of Self-Formulated Anti-Oxidant Mineral Formulation for Mastitis Management in Dairy Cattle
}

\author{
A. Muhee $^{1 *}$, H. U. Malik ${ }^{1}$, I. Asharaf ${ }^{1}$, O. S. Shah ${ }^{1}$, A. Jan ${ }^{1}$, Muheet ${ }^{1}$, \\ W. Rather ${ }^{1}$ and Showkeen Muzamil ${ }^{2}$ \\ ${ }^{1}$ Department of Veterinary Medicine ethics and Jurisprudence, F.V.Sc \& A.H, \\ SKUAST-K, Srinagar- 192301, Jammu and Kashmir, India \\ ${ }^{2}$ Molecular Biology Lab, Division of Veterinary Biochemistry, Faculty of Veterinary Sciences \& \\ Animal Husbandry, Sheri Kashmir University of Agricultural Science \& Technology-Kashmir \\ (SKUAST-K), Srinagar, J\&K-190006, India \\ *Corresponding author
}

A B S T R A C T

\begin{tabular}{|l|}
\hline Ke y w or d s \\
$\begin{array}{l}\text { Mastitis, mineral } \\
\text { mixture, } \\
\text { supplementation, Scc }\end{array}$ \\
\hline Article Info \\
\hline $\begin{array}{l}\text { Accepted: } \\
\text { 20 June } 2017 \\
\text { Available Online: } \\
\text { 10 July } 2017\end{array}$ \\
\hline
\end{tabular}

The study was undertaken on clinical cases of bovine mastitis presented to Teaching Veterinary Clinical Complex (TVCC), F.V.Sc \& A.H, SKUAST-K and adjoining areas during the course of study August 2014-May 2016. For prophylactic trials, Twenty recently parturated lactating animals maintained at Mountain Livestock Research Institute (MLRI), SKUAST-K, Manasbal under similar managemental conditions but having susceptibility to occurrence of mastitis (as evidenced by precedence to occurrence of mastitis in previous lactations) were studied. Animals were divided into two groups, Group I comprising of ten animals received self-formulated anti-oxidant trace mineral mixture for a period of thirty days while as the other group (Group II) did not receive any antioxidants. The feeding of anti-oxidant trace mineral formulation improves the udder health status indicating increased capability of udder to defend against the attack of pathogenic microorganisms responsible for causing mastitis and hence decreased susceptibility to the occurrence of mastitis. Anti-oxidant trace mineral supplementation like $\mathrm{Cu}, \mathrm{Zn}, \mathrm{Mn}$ and $\mathrm{Se}$ may play a significant role in prophylaxis of mastitis in lactating animals.

\section{Introduction}

Mastitis is characterized by a range of physical and chemical changes of the milk and pathological changes in the udder tissues (Radostits et al., 2007). It is still recognized as number one problem in dairy animals which results in great economic losses to the farmers due to reduced productivity and cost of treatment (DeGrave and Fetrow, 1993). So far, conventional antibiotic therapy is the only proven method for the prevention and control of mastitis, however, standard antibiotic treatment has not reduced the incidence of mastitis and antibiotics do not directly protect the gland from being damaged. In fact, several problems arise from the use of antibiotics for example, developing resistance to antibiotic, questionable drug efficacy and presence of antibiotic residues in the milk.

Additionally, mastitis causes a rise in antimicrobial usage (Grave et al., 1999). During mastitis there is a large increase in the 
SCC (Wergin et al., 1979). Neither it has been adequately controlled by vaccination because of diversified etiology. Scientists throughout the world are currently investigating the role of alternative medicine to combat this devastating disease. The ideal means of dealing with mastitis is to prevent it from occurring. Present study was therefore undertaken to evaluate the efficacy of feeding self- formulated anti-oxidant trace mineral mixture for mastitis prophylaxis.

Antioxidant supplementation could decrease the duration, incidence and severity of clinical mastitis as the formation of increased free radicals during mastitis are mostly associated with decreased antioxidant defence since substantial amounts of free radicals are produced during an inflammatory response such as that which occurs when the mammary gland becomes infected. Trace elements with anti-oxidant function include copper, zinc, manganese, iron and selenium which act as co-factors for anti-oxidant enzymes superoxide dismutase, catalase and glutathione peroxidase which are directly or indirectly involved in quenching or neutralising the excess free radicals generated due to oxidative stress.

\section{Materials and Methods}

Twenty recently parturated lactating animals maintained at Mountain Livestock Research Institute (MLRI), SKUAST-K, Manasbal under similar managemental conditions but having susceptibility to occurrence of mastitis (as evidenced by precedence to occurrence of mastitis in previous lactations)were studied. One group of animals (Group I)comprising of ten animals received self-formulated antioxidant trace mineral mixture for a period of thirty days while as the other group (Group II) did not receive any anti-oxidants. The antioxidant trace minerals were given at prophylactic doses as recommended by NRC,
2001.The composition of anti-oxidant trace mineral mixture is given in Appendix-I. The total dose per animal was 1.402 grams. Three hundred pouches were made and one pouch per animal per day was given to selected ten animals (Group I) for 30 days.

The efficacy of prophylactic treatment was evaluated by occurrence of mastitis during the course of therapy and one month after therapy, estimation of SCC in milk on day 0 , day 15 and day 30 of treatment in both the groups of animals. Mineral estimation for copper, zinc, manganese and Selenium was also done on day 0 , day 15 and day 30 to determine the effect of anti-oxidant trace mineral supplementation on their blood values. Both the groups of animals were monitored for occurrence of mastitis for a period of one month after stopping the therapy.

\section{Milk SCC}

The somatic cell count of milk samples was done by direct microscopic method. The test milk sample was thoroughly mixed and $10 \mu \mathrm{l}$ of milk was spread on one square $\mathrm{cm}\left(1 \mathrm{~cm}^{2}\right)$ demarcated area of a clean grease free glass slide. The smear of milk was prepared within one hour of its collection to minimise the disintegration of leukocytes and smear was dried at room temperature.

The smear was stained with modified Newman's Lampert stain for 1 to 2 minutes and then the smears were washed with tap water and dried. The dried stained smears were examined under oil immersion objective and the number of cells in 20 fields was counted. The fields were selected by moving the slide horizontally from one edge of the film through the centre to the opposite edge and then, repeated in a vertical direction. The average number of cells per field was multiplied by the microscopic factor. 
Calibration of the microscope/calculation of microscopic factor

The diameter of the microscopic field seen through oil immersion objective was measured using a stage micrometer slide ruled in 0.1 and $0.01 \mathrm{~mm}$. The diameter of the field was measured up to two decimal points and the area of the field was calculated using the formula $\Pi r^{2}$.

Area of the smear (in mm2) Microscopic factor (MF) =

Area of the microscopic field

The diameter was 0.16 , then $r=0.08$

$$
\text { So, } \mathrm{MF}=\frac{100}{3.14 \mathrm{X} 0.082}=4976 \approx 5000
$$

Since, the milk sample taken on the slide was $0.01 \mathrm{ml}$, the total number of cells per $\mathrm{ml}$ of milk was given by the formula,

Cell count per $\mathrm{ml}$ of milk $=$ Average No. of cells per field $\times \mathrm{MF} \times 100$

\section{Estimation of trace minerals}

Trace minerals like copper $(\mathrm{Cu})$, zinc $(\mathrm{Zn})$, manganese (Mn) and selenium (Se) were estimated from the plasma of both groups of animals. The plasma samples were digested using concentrated nitric acid (AR, $15 \mathrm{~mL}$ ) and each digested sample was diluted to 10 $\mathrm{mL}$ using double glass distilled water. The samples were analysed at Kashmir University, Hazratbal in the Department of University Scientific Instrumentation Centre (USIC) using Polarised Zeeman Atomic Absorption Spectrophotometer (Z-2300, Hitachi).

\section{Results and Discussion}

The mean somatic cell count (SCC) was $2.81 \pm 0.07,2.65 \pm 0.06$ and $2.48 \pm 0.03 \times 10^{5} / \mathrm{mL}$ of milk for group I animals on day 0, day 15 and day30 of treatment, respectively. The mean values for SCC $\left(\times 10^{5} / \mathrm{mL}\right.$ of milk) for group II animals were $2.81 \pm 0.06,2.77 \pm 0.06$ and $2.97 \pm 0.06$ on day 0 , day 15 and day 30 of study, respectively. The mean values of SCC on day 0 and day 15 of treatment in two groups of animals did not differ significantly from each other $(p>0.05)$ but the mean values of SCC on day 30 in two groups of animals differed significantly $(\mathrm{p}<0.05)$ from each other (Table 1). The difference in the mean values of SCC within the group I was statistically significant from each other on day 0 and day 30 as well as between day 15 and day 30 of treatment $(\mathrm{p}<0.05)$ while as the difference in the mean values of SCC between day 0 and day 15 of treatment was statistically non-significant $(p>0.05)$. The difference in the mean values of SCC within the group II was statistically significant between day 0 and day 30 of treatment $(\mathrm{p}<0.05)$ but statistically non-significant $(\mathrm{p}>0.05)$ between day 0 and day 15 as well as between day 15 and day 30 of treatment. As evidenced from the Table, group I animals showed a considerable improvement in milk SCC as compared to group II on day 15 and day 30 post treatment while as the animals in the group II showed an increase in the SCC on day 15 and 30 of treatment than day 0 .

\section{Trace mineral estimation}

The mean values for $\mathrm{Cu}(\mu \mathrm{mol} / \mathrm{L})$ were $8.08 \pm 0.08,8.26 \pm 0.06$ and $8.43 \pm 0.05$ ingroup I animals on day 0 and day 15 and day 30 of treatment, respectively (Table 15 \& Fig. XXII). The mean values for $\mathrm{Cu}(\mu \mathrm{mol} / \mathrm{L})$ for group II animals were $8.09 \pm 0.05,7.99 \pm 0.05$ and $7.88 \pm 0.04$ on day 0 , day 15 and day 30 of study, respectively. The mean values of copper on day 0 in two groups of animals did not differ significantly from other $(\mathrm{p}>0.05)$. The mean values of copper on day 15 and day 30 in two groups of animals differed significantly $(p<0.05)$ from each other (Table 
15\&Fig. XXII). The difference in the mean values of copper within the group I was statistically significant between day 0 and day30 of treatment $(p<0.05)$ but statistically non-significant between day 0 and day 15 as well as between day 15 and day 30 of treatment $(\mathrm{p}>0.05)$. The difference in the mean values of copper within the group II was statistically significant between day 0 and day 30 of treatment $(\mathrm{p}<0.05)$ but statistically nonsignificant $(p>0.05)$ between day 0 and day 15 as well as between day 15 and day 30 of treatment.

The mean values for $\mathrm{Zn}(\mu \mathrm{mol} / \mathrm{L})$ were $13.87 \pm 0.17,14.12 \pm 0.16$ and $14.56 \pm 0.14$ in group I animals on day 0 and day 15 and day 30 of treatment, respectively. The mean values for $\mathrm{Zn}(\mu \mathrm{mol} / \mathrm{L})$ for group II animals were $13.83 \pm 0.12,13.67 \pm 0.13$ and $13.53 \pm 0.14$ on day 0 , day 15 and day30 of study, respectively.

The mean values of zinc on day 0 in two groups of animals did not differ significantly from other $(p>0.05)$. The mean values of zinc on day 15 and day 30 in two groups of animals differed significantly from each other $(p<0.05) \quad$ (Table 15 \&Fig. XXII). The difference in the mean values of zinc within the group I was statistically significant between day 0 and day 30 of treatment $(\mathrm{p}<0.05)$ but statistically non-significant between day 0 and day 15 as well as between day 15 and day 30 of treatment ( $>00.05$ ).

The difference in the mean values of zinc within the group II was statistically significant between day 0 and day 30 of treatment $(\mathrm{p}<0.05)$ but statistically nonsignificant $(\mathrm{p}>0.05)$ between day 0 and day 15 as well as between day 15 and day 30 of treatment. The mean values for $\mathrm{Mn}(\mu \mathrm{mol} / \mathrm{L})$ were $3.65 \pm 0.08,3.95 \pm 0.08$ and $4.07 \pm 0.07$ in group I animals on day 0 and day 15 and day 30 of treatment, respectively (Table 15 \&Fig.
XXII). The mean values for $\mathrm{Mn}(\mu \mathrm{mol} / \mathrm{L})$ for group II animals were $3.36 \pm 0.11,3.32 \pm 0.10$ and $3.32 \pm 0.09$ on day 0 , day 15 and day 30 of study, respectively. The mean values of manganese on day 0 , day 15 and day 30 of treatment in two groups of animals differed significantly from other $(\mathrm{p}<0.05)$.

The difference in the mean values of manganese within the group I was statistically significant between day 0 and day 15 of treatment as well as between day 0 and day 30 of treatment $(\mathrm{p}<0.05)$ but statistically nonsignificant between day 15 and day 30 of treatment $(p>0.05)$. The difference in the mean values of Mn within the group II was statistically non-significant ( $p>0.05$ ) between day 0 , day 15 and day 30 of treatment (Table 15 \& Fig. XXII).

The mean values for $\mathrm{Se}(\mathrm{ng} / \mathrm{mL})$ were $38.81 \pm 1.56,40.78 \pm 1.46$ and $43.58 \pm 0.99$ in group I animals on day 0 and day 15 and day 30 of treatment, respectively. The mean values for $\mathrm{Se}(\mathrm{ng} / \mathrm{mL})$ for group II animals were $\quad 36.87 \pm 0.89, \quad 36.75 \pm 0.54 \quad$ and $36.47 \pm 0.46 \pm$ on day 0 ,day 15 and day30 of study, respectively.

The mean values of selenium on day 0 in two groups of animals did not differ significantly from other $(p>0.05)$. The mean values of selenium on day 15 and day 30 in two groups of animals differed significantly $(\mathrm{p}<0.05)$ from each other (Table 1).

The difference in the mean values of selenium within the group I was statistically significant between day 0 and day 15 as well as between day 0 and day 30 of treatment $(p<0.05)$ but statistically non-significant between day 15 and day 30 of treatment ( $>00.05)$. The difference in the mean values of selenium within the group II was statistically nonsignificant ( $p>0.05$ ) between day 0,15 and 30 of treatment. 
Table.1 Impact of prophylactic anti-oxidant trace mineral therapy on milk SCC and blood trace mineral profile of healthy lactating animals

\begin{tabular}{|c|c|c|c|}
\hline Parameters & $\begin{array}{c}\text { Days of } \\
\text { treatment }\end{array}$ & $\begin{array}{c}\text { Group I } \\
\text { (With anti-oxidants) }\end{array}$ & $\begin{array}{c}\text { Group II } \\
\text { (Without anti-oxidants) }\end{array}$ \\
\hline \multirow[t]{3}{*}{$\mathrm{SCC}\left(\times 10^{5} / \mathrm{mL}\right)$} & Day 0 & $2.81 \pm .07^{\mathrm{al}}$ & $2.81 \pm .06^{\mathrm{aI}}$ \\
\hline & Day 15 & $2.65 \pm .06^{\mathrm{al}}$ & $2.77 \pm .06^{\mathrm{a} 1,2}$ \\
\hline & Day 30 & $2.48 \pm .03^{\mathrm{a} 2}$ & $2.97 \pm .07^{\mathrm{b} 2}$ \\
\hline \multirow[t]{3}{*}{ Copper $(\mu \mathrm{mol} / \mathrm{L})$} & Day 0 & $8.08 \pm .08^{\mathrm{al}}$ & $8.09 \pm .05^{\mathrm{al}}$ \\
\hline & Day 15 & $8.26 \pm .06^{\mathrm{a} 1,2}$ & $7.99 \pm .05^{\mathrm{b} 1,2}$ \\
\hline & Day 30 & $8.43 \pm .05^{\mathrm{a} 2}$ & $7.88 \pm .04^{\mathrm{b} 2}$ \\
\hline \multirow[t]{3}{*}{ Zinc $(\mu \mathrm{mol} / \mathrm{L})$} & Day 0 & $13.87 \pm .17^{\mathrm{a} \perp}$ & $13.83 \pm .12^{\mathrm{a} 1}$ \\
\hline & Day 15 & $14.13 \pm .16^{\mathrm{a} 1,2}$ & $13.67 \pm .13^{b 1}$ \\
\hline & Day 30 & $14.56 \pm .14^{\mathrm{a} 2}$ & $13.54 \pm .14^{\mathrm{bl}}$ \\
\hline \multirow{3}{*}{$\begin{array}{l}\text { Manganese } \\
(\mu \mathrm{mol} / \mathrm{L})\end{array}$} & Day 0 & $3.65 \pm .08^{\mathrm{al}}$ & $3.36 \pm .11^{\mathrm{bl}}$ \\
\hline & Day 15 & $3.95 \pm .08^{\mathrm{a} 2}$ & $3.32 \pm .10^{\mathrm{bI}}$ \\
\hline & Day 30 & $4.07 \pm .07^{\mathrm{a} 2}$ & $3.32 \pm .09^{\mathrm{bl}}$ \\
\hline \multirow[t]{3}{*}{$\mathrm{Se}(\mathrm{ng} / \mathrm{mL})$} & Day 0 & $38.81 \pm 1.56^{\mathrm{a} \perp}$ & $36.87 \pm .89^{\mathrm{a}}$ \\
\hline & Day 15 & $40.78 \pm 1.46^{\mathrm{a} 1,2}$ & $36.75 \pm .54^{b 1}$ \\
\hline & Day 30 & $43.58 \pm .99^{\mathrm{a} 2}$ & $36.47 \pm .46^{\mathrm{bl}}$ \\
\hline
\end{tabular}

Values within a row having superscript $(\mathrm{a}, \mathrm{b})$ with at least one common alphabet do not differ significantly at $5 \%$ level $(\mathrm{p}<0.05)$ from each other.

Values within a column having superscript $(1,2,3)$ with at least one common numerical do not differ significantly at $5 \%$ level $(\mathrm{p}<0.05)$ from each other.

Table.2 Impact of prophylactic anti-oxidant trace mineral therapy on milk SCC and occurrence of clinical mastitis of healthy lactating animals 15 days after stopping the therapy.

\begin{tabular}{|l|c|c|}
\hline \multicolumn{1}{|c|}{ Parameter } & $\begin{array}{c}\text { Group I(With anti- } \\
\text { oxidants) }\end{array}$ & $\begin{array}{c}\text { Group II(Without } \\
\text { anti-oxidants) }\end{array}$ \\
\hline SCC $\left(\times 10^{5} / \mathrm{mL}\right)$ & $2.72 \pm .09^{\mathrm{a}}$ & $3.07 \pm .06^{\mathrm{b}}$ \\
\hline Occurrence of clinical mastitis & $0 / 10$ & $2 / 10$ \\
\hline
\end{tabular}

As evidenced from the Table, group I animals showed a considerable improvement in trace mineral status as compared to group II on day 15 and day 30 post treatment. However, the animals in group II did not show any increase in the values but a slight decline in the levels of trace minerals on day 15 and 30 of treatment.

The animals were monitored for a total period of one month after stopping the treatment for occurrence of mastitis. Milk SCC was lower in the group I animals as compared to group II animals as depicted in Table 2. Clinical mastitis was observed in two animals of group II while as none of the animals in group I suffered from clinical mastitis during the course of study nor one month after the study.

Our findings indicate that feeding of trace minerals improves the udder health status of dairy cattle. The reason for decreased SCC and improved udder health status in group I animals is because feeding of trace minerals ameliorated the oxidative stress thereby improving the udder health status and 
immunity in group I animals. It signifies the better efficiency of group I animals than group II in combating the attack of pathogenic microorganisms responsible for causing mastitis and decreased susceptibility to the occurrence of mastitis in this group as compared to the control group.

The present study findings are in agreement with Machado et al., (2013), who reported that dairy cows supplemented with a combination of different trace elements (Se, $\mathrm{Cu}, \mathrm{Zn}$ and $\mathrm{Mn}$ ) showed lower SCC levels (decreased incidence of mastitis) in comparison to the control cows. Sordillo and Mavangira (2014) also advocated controlling mastitis through appropriate antioxidant supplementation in terms of trace mineral supplementation that could potentially boost the animals' health status and performance.

The feeding of anti-oxidant trace mineral formulation improves the udder health status indicating increased capability of udder to defend against the attack of pathogenic microorganisms responsible for causing mastitis and hence decreased susceptibility to the occurrence of mastitis. Anti-oxidant trace mineral supplementation like $\mathrm{Cu}, \mathrm{Zn}, \mathrm{Mn}$ and Se may play a significant role in prophylaxis of mastitis in lactating animals.

\section{Appendix - I}

Prophylactic dose of mineral mixture:

Copper sulphate: $500 \mathrm{mg}$

Zinc sulphate: $500 \mathrm{mg}$

Manganese sulphate: $400 \mathrm{mg}$
Selenium: $2 \mathrm{mg}$

Total Dose: 1.042g/animal/day for 30 days

\section{References}

DeGrave, F.J. and Fetrow, J. 1993. Economics of mastitis and mastitis control. Vet. Clin. North America, Food Animal Practice, 9: 421.

Grave, K. et al., 1999. The usage of veterinary antibacterial drugs for mastitis in cattle in Norway and Sweden during 1990-1997. Preventive Vet. Med., (42): 45-55.

Machado, V. S., Bicalho, M. L. S., Pereira, R. V., Caixeta, L. S., Knauer, W. A., Oikonomou, G., Gilbert, R. O. and Bicalho, R. C. 2013. Effect of an injectable trace mineral supplement containing selenium, copper, zinc, and manganese on the health and production of lactating Holstein cows. Veterinary Journal197:451-456.

Paape, M.J., Wergin, W.P., Guidry, A.J., Pearson, R.E. 1979. Leukocytes 2nd line of defense against invading mastitis pathogens. J. Dairy Sci., 62: 135-153.

Radostits, O. M., Gay, C. C, Hinchcliff, K. W. and Constable, P. D. 2007. VeterinaryMedicine $\left(10^{\text {th }} \mathrm{edn}\right.$.): A Text Book of Diseases of Cow, Buffalo, Horse, Sheep, Goat and Pig. W B Saunders Company Ltd. ISBN: 0702027774.

Sordillo, L. M. and Mavangira, V. 2014. The nexus between nutrient metabolism, oxidative stress and inflammation in transition cows. Animal Production Science 54:1204-1214.

\section{How to cite this article:}

Muhee A., H. U. Malik, I. Asharaf, O. S. Shah, A. Jan, Muheet, W. Rather and Showkeen Muzamil. 2017. Prophylactic Efficacy of Self-Formulated Anti-Oxidant Mineral Formulation for Mastitis Management in Dairy Cattle. Int.J.Curr.Microbiol.App.Sci. 6(7): 4609-4614. doi: https://doi.org/10.20546/ijcmas.2017.607.483 